............................

Neuroendovascular Surgery 


\section{Progress in Neurological Surgery}

\section{Vol. 17}

Series Editor

L. Dade Lunsford Pittsburgh, Pa. 


\section{…………………. \\ Neuroendovascular Surgery}

Volume Editors

Michael B. Horowitz Pittsburgh, Pa.

Elad I. Levy Buffalo, N.Y.

55 figures and 8 tables, 2005

KARGER $\quad \begin{aligned} & \text { Basel } \cdot \text { Freiburg } \cdot \text { Paris } \cdot \text { London } \cdot \text { New York } \\ & \text { Bangalore } \cdot \text { Bangkok } \cdot \text { Singapore } \cdot \text { Tokyo } \cdot \text { Sydney }\end{aligned}$ 


\author{
Michael B. Horowitz, MD \\ Department of Neurosurgery \\ Director, Neuroendovascular Surgery \\ UPMC Presbyterian \\ Suile B-400, 200 Lothrop Street \\ Pittsburgh, PA 15213-2582 (USA) \\ Elad I. Levy, MD \\ Millard Filmore Hospital \\ Dept. of Neurosurgery \\ 3 Gates Circle \\ Buffalo, NY 14209-1194
}

\author{
Library of Congress Cataloging-in-Publication Data \\ Neuroendovascular surgery / volume editors, Michael Horowitz, Elad Levy. \\ p. ; cm. - (Progress in neurological surgery, ISSN 0079-6492 ; v. 17) \\ Includes bibliographical references and index. \\ ISBN 3-8055-7781-8 (hard cover : alk. paper) \\ 1. Nervous system-Blood-vessels-Endoscopic surgery. \\ [DNLM: 1. Nervous System Diseases-surgery. 2. Vascular \\ Diseases-surgery. 3. Neurosurgical Procedures. 4. Vascular Surgical \\ Procedures. WL 368 N4942 2004] I. Horowitz, Michael S. II. Levy, Elad. \\ III. Series. \\ RD594.2.N455 2004 \\ $617.4^{\prime} 8-\mathrm{dc} 22$
}

2004013518

Bibliographic Indices. This publication is listed in bibliographic services, including Current Contents ${ }^{\circledR}$ and Index Medicus.

Drug Dosage. The authors and the publisher have exerted every effort to ensure that drug selection and dosage set forth in this text are in accord with current recommendations and practice at the time of publication. However, in view of ongoing research, changes in government regulations, and the constant flow of information relating to drug therapy and drug reactions, the reader is urged to check the package insert for each drug for any change in indications and dosage and for added warnings and precautions. This is particularly important when the recommended agent is a new and/or infrequently employed drug.

All rights reserved. No part of this publication may be translated into other languages, reproduced or utilized in any form or by any means electronic or mechanical, including photocopying, recording, microcopying, or by any information storage and retrieval system, without permission in writing from the publisher.

(C) Copyright 2005 by S. Karger AG, P.O. Box, CH-4009 Basel (Switzerland)

www.karger.com

Printed in Switzerland on acid-free paper by Reinhardt Druck, Basel

ISSN 0079-6492

ISBN 3-8055-7781-8 


\section{Contents}

VII Series Editor's Note

Lunsford, L.D. (Pittsburgh, Pa.)

IX Foreword

Horowitz, M.B. (Pittsburgh, Pa.); Levy, E.I. (Buffalo, N.Y.)

1 Current and Future Management Strategies for Intracranial Aneurysms and Carotid Artery Stenosis

Deshaies, E.M.; Boulos, A.S. (Albany, N.Y.)

18 The Use of Stents in the Management of Neurovascular Disease: A Historical and Present Status Review Horowitz, M.B.; Purdy, P.D. (Pittsburgh, Pa.)

32 Carotid Angioplasty with Stenting and Carotid Endarterectomy: Both Are Here to Stay

Hanel, R.A.; Levy, E.I.; Guterman, L.R.; Hopkins, L.N. (Buffalo, N.Y.)

54 Endovascular Treatment of Acute Ischemic Embolic Stroke Ionita, C.C.; Kim, S.H.; Xavier, A.R. (Buffalo, N.Y.); Kirmani, J.F.; Siddiqui, A.M.; Qureshi, A.I. (Newark, N.J.)

70 Intracranial Stenting

Harrigan, M.R.; Levy, E.I.; Guterman, L.R.; Hopkins, L.N. (Buffalo, N.Y.)

85 Angioplasty for Repair of Intracranial Arterial Stenosis

Ringer, A.J. (Cincinnati, Ohio) 
101 Endovascular Therapy for Intracranial Aneurysms: A Historical and Present Perspective

Horowitz, M.B. (Pittsburgh, Pa.); Levy, E.I. (Buffalo, N.Y.); Kassam, A.;

Purdy, P.D. (Pittsburgh, Pa.)

122 Endovascular Management of Wide-Necked Aneurysms

Horowitz, M.B. (Pittsburgh, Pa.); Levy, E.I. (Buffalo, N.Y.)

135 Liquid Embolic Agents in the Treatment of Intracranial Arteriovenous Malformations

Howington, J.U. (Buffalo, N.Y.); Kerber, C.W. (San Diego, Calif.);

Guterman, L.R.; Hopkins, L.N. (Buffalo, N.Y.)

148 Management of Arteriovenous Malformations Using Liquid Agents

Ozgur, B.M.; Levy, D.I. (San Diego, Calif.)

160 Treatment of Dural Arteriovenous Fistulas

Feng, L.; Meyers, P.M.; Higashida, R.T. (New York, N.Y.)

180 Tumor Embolization

Levy, E.I. (Buffalo, N.Y.); Spiro, R.; Horowitz, M.B.;

Hanel, R. (Pittsburgh, Pa.)

194 Acute and Chronic Venous Sinus Thrombosis

Horowitz, M.B.; Greenlee, R.G., Jr.; Jungreis, C.A.; Purdy, P.D. (Pittsburgh, Pa.)

216 Vein of Galen Aneurysms: A Review and Current Perspective

Horowitz, M.B.; Jungreis, C.A.; Quisling, R.G.; Pollack, I. (Pittsburgh, Pa.)

232 Petrosal Sinus Sampling for Cushing's Disease

Horowitz, M.B. (Pittsburgh, Pa.); Levy, E.I. (Buffalo, N.Y.); Genevro, J.;

Kassam, A.; Burguera, B. (Pittsburgh, Pa.)

239 Author Index

240 Subject Index 


\section{Series Editor's Note}

Perhaps the most profound change in the delivery of neurosurgical health care in the last ten years represents the rapid incorporation of endovascular techniques into the armamentarium of options for neurosurgical patients with cerebrovascular and spinal disease. Based on the histological principles of intravascular localization begun by the neurologist, Egas Moniz, in Portugal in the late 1920 's, and pursued by both neurosurgeons, radiologists and neurologists over the ensuing $80+$ years, the ability to perform miracles from within the blood vessels has now become a reality. The myriad of applications ranges from treatment of acute strokes ('brain attack', a condition with much greater morbidity than heart attack), aneurysm management, carotid occlusive disease, adjuvant tumor embolization prior to planned surgical excision, management for arteriovenous malformations, and now the insertion of stents, coils, and adhesive agents. By partnering with industry, we see the examples of this remarkable trend in minimally invasive (or as the series editors prefer 'minimally intrusive') options. We see a concomitant reduction in hospital stays, lessening of hospital costs, reduced morbidity, and increasingly better outcomes. Stroke is no longer an event with severe long term repercussions, it represents instead an opportunity to emergently intervene to keep the blood vessel open, restore cerebral blood flow function, and maintain quality of life. These technologies continue to mature and to progress. The enclosed volume represents a state of the art summary of current techniques, and also provides glimpses of the future. Pioneers in the usage of these technologies have preceded this work. I hope that the knowledge contained in this book will spur the next generation onto even greater achievements. All of us, the present and the 
future generation, needs to become educated in these techniques, as the world of brain and spinal surgery matures, grows, and transforms.

L. Dade Lunsford, MD 


\section{Foreword}

Many surgical subspecialties over the past decades have moved towards what has been termed minimally invasive approaches to traditionally open procedures. Endoscopy comes to mind whenever one considers this trend as it has either revolutionized or has begun to revolutionize General Surgery, Otolaryngology, Urology, Neurosurgery, and Cardiothoracic Surgery. Endovascular surgical procedures first drastically altered the surgical landscape as they pertained to coronary bypass and are now providing alternatives for repair of other cardiac and vascular anomalies such as septal defects, peripheral arterial occlusions and stenoses, peripheral aneurysms, and carotid disease. With the advent of improved technology and smaller maneuverable devices more delicate procedures have been developed such as those to occlude cerebral aneurysms, occlude arteriovenous malformations, eliminate blood supply to tumors, and treat extracranial and intracranial arterial stenoses. However, because all of these procedures carry risk and are ultimately as invasive as open surgical procedures we prefer to use the term minimally intrusive surgery for those endovascular procedures that are discussed in the coming chapters. These procedures gain access to the target lesion without disrupting or destroying surrounding tissues such as skin, muscle, bone, and brain. As a result pain is minimized and recovery is ideally facilitated and shortened.

The purpose of this text is to discuss the most common neuroendovascular procedures currently practiced. Less commonly performed procedures such as intra-arterial chemotherapy and sclerotherapy have been omitted not because we consider them unimportant but because space was limited. We hope that the 
readers find this book to be a useful resource when investigating the most frequently conducted endovascular procedures.

We would like to thank the many chapter authors for their contributions and encourage all entering this field to expand the horizons as this field is limited only by our imaginations and the abilities of talented engineers.

Michael B. Horowitz, MD Elad I. Levy, MD 